\title{
Pengelolaan Lingkungan Sekolah sebagai Laboratorium Alam Berbasis Partisipatif
}

\author{
Ahmad Damanhuri ${ }^{(1)}$ \\ 'SMAN 01 Blitar \\ Email: ${ }^{1}$ ahmaddamanhurismasa@gmail.com \\ DOI:http://doi.org/10.28926/riset_konseptual.v2i4.119
}

\begin{abstract}
ABSTRAK.
Pembelajaran kontekstual dapat meningkatkan aktivitas siswa dalam proses pembelajaran, sehingga siswa memiliki keterampilan berpikir kritis. Dengan pembelajaran kontekstual dan pembelajaran berbasis lingkungan sebagai laboratorium alam, siswa diharapkan mampu memanfaatkan sumber belajar secara maksimal. Berbekal predikat Sekolah Adiwiyata Nasional, SMA Negeri 1 Blitar, mengembangkan pengelolaan lingkungan sekolah sebagai laboratorium alam berbasis partisipatif. Dengan adanya kegiatan tersebut sekolah diharapkan mampu mengimplementasikan nilai karakter budaya dan peduli lingkungan melalui berbagai kegiatan sekolah. Dengan penataan lingkungan sekolah diharapkan dapat membawa dampak secara langsung terhadap siswa maupun guru, terutama pada motivasi belajar siswa dan hasil belajar siswa.
\end{abstract}

\section{Kata kunci: natural laboratory, participate based}

\section{PENDAHULUAN}

Proses pembelajaran di sekolah merupakan suatu proses yang penting dan harus disusun dengan baik oleh seorang guru. Pembelajaran sebagai proses belajar yang dibangun oleh guru untuk mengembangkan kreatifitas berpikir yang dapat meningkatkan kemampuan berpikir siswa, serta dapat meningkatkan kemampuan mengkontruksi pengetahuan baru sebagai upaya meningkatkan penguasaan yang baik terhadap materi. Pembelajaran merupakan sebuah proses interaksi antara peserta didik dengan pendidik dan sumber belajar dalam suatu lingkungan belajar. (UU No 20 Tahun 2003 Tentang SISDIKNAS pasal 1 ayat 20). Proses pembelajaran meliputi kegiatan mengajar dan belajar, dimana guru sebagai pelaku yang mengajar dan peserta didik sebagai pelaku yang belajar.

Pengalaman belajar melalui interaksi langsung dengan alam atau lingkungan akan memberikan pengalaman belajar yang lebih berkesan bagi perserta didik. Belajar melalui pembelajaran kontekstual merupakan salah satu strategi yang dapat ditempuh untuk memberikan pengalaman langsung kepada peserta didik. Pembelajaran kontekstual merupakan konsep belajar yang membantu guru mengaitkan antara materi yang diajarkan dengan situasi dunia nyata dan mendorong siswa membuat hubungan pengetahuan yang dimilikinya dengan penerapannya dalam kehidupan mereka sebagai anggota keluarga dan masyarakat, proses pembelajaran berlangsung alamiah dalam bentuk kegiatan siswa bekerja dan mengalami, bukan mentransfer pengetahuan dari guru ke siswa, strategi pembelajaran lebih dipentingkan daripada hasil (Sudrajat, 2008: 2).

Pembelajaran Kontekstual (Contextual Teaching and Learning) merupakan pembelajaran yang berfokus pada kegiatan siswa yang melibatkan penerapan konstruktivisme, menemukan, bertanya, masyarakat belajar, pemodelan, refleksi, dan penilaian yang sebenarnya. Mardianti (2011) menambahkan bahwa pembelajaran kontekstual memberikan pengaruh terhadap hasil belajar dan respon positif terhadap mata pelajaran, karena siswa terlibat langsung dalam proses belajar mengajar dan mengaitkan langsung konsep yang dipelajari dengan kehidupan sehari-hari.

Guru dapat memberikan pengalaman belajar secara langsung kepada peserta 
didik dengan memanfaatkan lingkungan sekolah. Hal ini sejalan dengan yang dikemukakan oleh Marijan (2012) bahwa salah satu cara memberikan pengalaman belajar bermakna bagi peserta didik yang nantinya diharapkan dapat meningkatkan kualitas pembelajaran adalah dengan mengoptimalkan pemanfaatan sumber belajar dari lingkungan sekitar sekolah. Tidak hanya terbatas pada sebagai sumber belajar tetapi juga media belajar sekaligus laboratorium.

Laboratorium sebagai sarana pendukung dalam pembelajaran sangan diperlukan. Menurut Moedjadi (1979: 12) laboratorium adalah tempat dimana percobaan dan penyelidikan dilakukan. Laboratorium dapat berupa ruang tertutup maupun ruang terbuka. Oleh karena itu, guru dapat menggunakan alam sebagai laboratorium. Pemanfaatan laboratorium alam akan memberikan kesempatan kepada siswa secara langsung untuk berinteraksi dengan alam dan permasalahan nyata yang ada di lingkungan sekitar.

Pembelajaran berbasis lingkungan memiliki beberapa keuntungan antara lain: 1) lingkungan menyediakan berbagai hal yang dipelajari oleh peserta didik, 2) kegiatan belajar lebih menarik, 3) proses pembelajaran lebih bermakna, 4) aktivitas peserta didik lebih meningkat, dan 5) terjadi pembentukan karakter pribadi peserta didik (Winaputra, 2006; dalam Marijan, 2012). Marijan (2012) menambahkan bahwa lingkungan sekolah menyediakan hal-hal nyata dan benda-benda konkrit yang dapat dijadikan contoh untuk menanamkan konsep. Ketersediaan lingkungan sekolah yang cukup luas dan memiliki berbagai jenis lingkungan yang berbeda akan memberikan banyak kesempatan bagi guru dan siswa untuk memanfaatkannya sebagai laboratorium alam.

SMA Negeri 1 Blitar memiliki luas 5 hektar dan memiliki sarana dan prasarana yang banyak. Selain bangunan terdapat pula berbagai macam lingkungan yang berbeda, seperti lapangan upacara, lapangan olahraga, hutan, kolam, Green House, pertanian organik, kebun belimbing, dan lain sebagainya. Masing-masing lingkungan memiliki ciri khas, kompleksitas, dan daya tarik yang berbeda-beda.

Pada tahun 2014 SMA Negeri 1 Blitar mendapat anugrah sebagai Sekolah Adiwiyata Nasional. Melalui program ini sekolah berusaha mengelola lingkungan sekolah sebagai implementasi program Kementerian Negara Lingkungan Hidup. Menurut Kementerian Negara Lingkungan Hidup (2009:3) Pendidikan Lingkungan Hidup yang sudah dikembangkan semenjak tanggal 21 Pebruari 2006 yang diterapkan melalui program Adiwiyata, dengan tujuan mendorong warga sekolah khususnya siswa untuk peduli dan berbudaya lingkungan sekaligus mendukung dan mewujudkan sumber daya manusia yang memiliki karakter bangsa terhadap perkembangan ekonomi, sosial, dan lingkungannya dalam mencapai pembangunan berkelanjutan.

Predikat Sekolah Adiwiyata Nasional telah diperoleh SMA Negeri 1 Blitar pada tahun 2014, predikat ini dapat dicapai melalui pengelolaan lingkungan sekolah berbasis partisipatif, dimana seluruh warga sekolah ikut berperan aktif dalam pengelolaan lingkungan. Dengan adanya kegiatan lingkungan berbasis partisipatif sekolah mampu mengimplementasikan nilai karakter melalui berbagai kegiatan sekolah. Setiap kegiatan sekolah harus mengitegrasikan karakter dan budaya cinta lingkungan, bahkan dalam kegiatan pembelajaran. Lingkungan SMA Negeri 1 Blitar yang luas dan variasi lingkungan sekitar sekolah sangat mendukung pemanfaatan lingkungan sekolah sebagai laboratorium alam. Siswa dapat belajar melalui alam sebagai sumber belajar. Siswa juga dapat belajar di alam bebas atau di luar kelas untuk mengurangi kebosanan siswa yang hanya belajar di dalam kelas ataupun laboratorium.

Guru dapat merancang suatu kegiatan pembelajaran dengan memanfaatkan alam sebagai laboratorium sekaligus menanamkan karakter dan budaya cinta lingkungan melalui interaksi langsung. Tetapi Wilyana menemukan bahwa pemanfaatan lingkungan sekolah tidak selamanya memiliki pengaruh signifikan terhadap hasil belajar karena harus didukung oleh variasi dan kompleksitas lingkungan sekitar sekolah, waktu belajar, kemampuan siswa, dan konsentrasi siswa ketika belajar di luar kelas. Oleh karena itu, diperlukan kreativitas guru dalam menyusun kegiatan pembelajaran sehingga pemanfaatan lingkungan sekolah sebagai labortorium alam dapat optimal. 
Berdasarkan pemikiran-pemikiran diatas, pengelolaan lingkungan sekolah berbasis partisipatif dengan lingkungan sekolah sebagai laboratorium alam dapat digunakan di SMA Negeri 1 Blitar sebagai upaya peningkatan motivasi dan hasil belajar siswa sekaligus dalam rangka menumbuhkan karakater budaya dan peduli lingkungan.

Mengacu pada latar belakang masalah, maka permasalahan yang dapat dikemukakan dalam best practice ini adalah sebagai berikut: 1)Bagaimanakah pemanfaatan lingkungan sekolah sebagai laboratorium alam di SMA Negeri 1 Blitar? dan 2)Bagaimanakah pemanfaatan laboratorium alam dapat digunakan sebagai sarana pengelolaan lingkungan sekolah berbasis paritisipatif?

Salah satu permasalahan utama dari penataan lingkungan di SMAN 1 Blitar adalah bagaimana melakukan pengelolaan lahan yang luas dengan keterbatasan sumber daya manusia/tenaga kebersihan dan keterbatasan anggaran yang ada. Adapun strategi yang dilakukan untuk mengatasi permasalahan lingkungan tersebut adalah dengan pengelolaan lingkungan sekolah sebagai laboratorium alam berbasis partisipatif.

\section{METODE}

Penelitian yang berjudul "Pengelolaan Lingkungan Sekolah sebagai Laboratorium Alam Berbasis Partisipatif" ini objek penelitiannya adalah lingkungan di SMAN 1 Blitar yang pemanfaatannya diharapkan bisa menjadi laboratorium alam. Penelitian ini memfokuskan pada data yang berbasis partisipatif.

Penelitian ini menggunakan metode kualitatif yaitu metode penelitian yang menghasilkan data berupa kata-kata tertulis. Metode kualitatif dipilih karena pada penelitian ini yang diteliti adalah lingkungan alam.

Suatu penelitian tidak lepas dari penggunaan metode. Dalam hal ini metode merupakan alat yang penting untuk mencapai tujuan yang telah ditentukan. Di-samping itu metode merupakan cara kerja yang dilakukan peneliti agar hasil penemuannya sesuai dengan yang diharapkan dalam penelitiannya. Hal ini sesuai dengan pendapat Nanang Suharmanto (dalam Yudiono, 1986: 14) bahwa penggunaan metode sangat menentukan keberhasilan sebuah penelitian karena merupakan cara memahami suatu objek penelitian. Bedasarkan pamahaman di atas, maka dapat disimpulkan bahwa metode yang digunakan dalam penelitian ini adalah metode kualitatif.

\section{Hasil/dampak yang dicapai}

\section{HASIL}

Dalam kegiatan pengelolaan sekolah sebagai laboratorium alam berbasis partisiatif guru mengajak siswa untuk melaksanakan penyelidikan ilmiah berupa eksperimen yang dilakukan di dalam kelas dan observasi di laboratorium alam. Selama pelaksanaan penyelidikan ilmiah, siswa tampak aktif dan antusias. Hal ini disebabkan pada pembelajaran sebelumnya siswa tidak pernah melakukan pembelajaran di luar kelas. Selain itu pelaksanaan praktikum juga jarang dilakukan oleh guru bidang studi yang bersangkutan. Menurut Rooijakkers, Ad. (1991:72) guru harus mampu membuat variasi-variasi dalam pembelajaran karena hal ini mempunyai dampak yang positif bagi siswa karena siswa tidak akan cepat bosan dan proses belajar akan berjalan lebih efisien.

Dengan pelaksanaan kegiatan laboratorium alam ini, siswa menjadi lebih antusias dalam proses belajar mereka. Selain itu siswa dituntut untuk menemukan sendiri konsep penting melalui kegiatan mengamati, menanya, menganalisis serta merumuskan teori dengan menggunakan keterampilan berpikir kritis. Tahapan-tahapan agar siswa menemukan sendiri konsep penting melalui pengalaman belajar disebut inkuiri. Sebagai tindak lanjut dari adanya konsep yang berhasil dtemukan oleh siswa, maka diharapkan siswa bisa mengaplikasikan sebuah tindakan nyata untuk mengelola lingkungan sekolah. Tindakan nyata dimulai dengan adanya masalah yang ditemukan pada tahap observasi di laboratorium alam.

Sejalan dengan Peratuan Pemerintah Nomor 32 Tahun 2013 Tentang Perubahan atas PP Nomor 19 Tahun 2005 Tentang Standar Nasional Pendidikan 
Pasal 49 Ayat (1) menyatakan: "Pengelolaan satuan pendidikan pada jenjang pendidikan dasar dan menengah menerapkan manajemen berbasis sekolah yang ditunjukkan dengan kemandirian, kemitraan, partisipasi, keterbukaan, dan akuntabilitas" Partisipatif dimaksudkan sebagai keikutsertaan semua pemangku kepentingan yang terkait dengan sekolah dalam mengelola sekolah dan pembuatan keputusan.

Usulan usulan siswa yang menjadi penterjemahan pola berpikir kritis setelah menemukan konsep menjadi landasan yang kuat untuk pengelolaan sekolah.Siswa mengusulkan berbagai hal terkait laboratorium alam, seperti misalnya mengusulkan penambahan berbagai jenis tanaman yang berbeda jenisnya pada saat siswa belajar tentang keanekaragaman hayati di laboratorium alam. Usulan tersebut berangkat dari adanya konsep keanekaragaman hayati yang ditangkap oleh siswa dan kemudian siswa menjadi tergerak untuk menambahn keanekaragaman hayati di lingkungan sekolah.

Sebagai sebuah tindakan yang didasari atas kepentingan akademis dan manajemen berbasis sekolah, maka tindakan pengelolaan lingkungan sekolah sebagai laboratorium alam berbasis partisipatif memiliki dampak yang baik dari sisi akademis dan adiwiyata, mengingat adanya pola belajar inquiri dan bersifat kontekstual serta adanya tindak lanjut berupa langkah nyata dalam hal pengelolaan lingkungan sekolah yang didasari partisipasi siswa (masayarakat, orang tua siswa), sehingga prinsip manajemen berbasis sekolah dapat terlaksana dengan baik.

\section{Kendala yang dihadapi}

Kendala yang dihadapi pada pengelolaan sekolah sebagai laboratorium alam antara lain: 1)Keterbatasan jumlah titik kegiatan/ pos kegiatan 2)Ada beberapa kelas yang jaraknya cukup jauh dengan titik/ pos kegiatan 3)Keterbatasan dana dan pos anggaran yang spesifik pada kegiatan tertentu. Kendala yang dihadapi pada pengelolaan sekolah sebagai laboratorium alam berbasis partisipatif antara lain: 1)Keterbatasan waktu, tidak setiap hari kegiatan yang memanfaatkan laboratorium alam dilakukan oleh siswa 2)Untuk menyelesaikan RPP yang memuat kegiatan berbasis laboratorium alam diperlukan waktu lebih lama.

\section{Faktor pendukung}

Faktor pendukung pada pengelolaan sekolah sebagai laboratorium alam antara lain: 1)Lahan terbuka hijau masih luas 2)Sekolah sudah menyandang predikat Adiwiyata Nasional. Faktor pendukung pada pengelolaan sekolah sebagai laboratorium alam berbasis partisipatif antara lain: 1)Tingkat ekonomi orang tua siswa yang cenderung lebih baik 2)Peran komite sekolah yang cukup besar 3)Dukungan alumni terhadap pembangunan sarana dan prasarana sekolah.

\section{Alternatif pengembangan}

Untuk mendapatkan hasil dan dampak yang lebih baik lagi, alternatif pengembangan yang dapat ditempuh antara lain :1)Menambah jumlah mapel yang berperan pada pemanfaatan lingkungan sekolah sebagai laboratorium alam yang sekaligus akan berpengaruh pada bertambahnya jumlah warga yang terlibat dalam kegiatan partisipatif 2)Menambah titik pos kegiatan, sehingga siswa tidak terkonsentrasi pada titik tertentu dan seluruh taman termanfaatkan 3)Mengundang siswa dari luar, supaya bisa menjadi ajang untuk menginduksi pada sekolah-sekolah lain 4)Pada saat siswa atau warga sekolah lain berkunjung ke sekolah pelaku (SMAN 1 Blitar), dapat ditampilkan atau dijual produk kewirausahaan siswa.

\section{Alasan Pemilihan Strategi}

\section{PEMBAHASAN}

Berikut ini adalah analisis SWOT yang dijadikan dasar pemilihan strategi untuk mengatasi permasalahn lingkungan dengan laboratorium alam berbasisi partisipatif. 
Latar belakang yang menjadi kekuatan (STRENGTH) yaitu: 1)Potensi luas lahan sehingga memungkinkan ruang terbuka hijau yang memadai 2)Sumber daya manusia yang memadai, sedang yang menjadi kelemahan (WEAKNESS) yaitu: 1)Keterbatasan jumlah petugas kebersihan dan terpusat pada managerial 2)Keterbatasan laboratorium yang berdampak pada motivasi dan hasil belajar siswa, dan tindak lanjut yang menjadi peluang (OPPORTUNITY) yaitu: 1)Potensi kreativitas dan prestasi siswa pada bidang akademis maupun non akdemis 2)Pembelajaran autentik, langsung belajar dari alam membuat dapat meningkatkan motivasi siswa, sedangkan yang menjadi ancaman ( THREAT) yaitu: 1)Pengelolaan lingkungan berbasis partisipatif oleh siswa di bawah bimbingan sekolah 2)Laboratorium alam sebagai sarana belajar untuk meningkatkan hasil belajar dan dan menggali gagasan siswa untuk pengelolaan lingkungan.

Strategi yang dipilih dalam proses pengelolaan ini harus memiliki nilai manfaat secara langsung kepada siswa. Nilai manfaat yang di dapatkan oleh siswa adalah meningkatnya hasil belajar siswa sebagai akibat terlaksananya strategi tersebut. Potensi jumlah siswa dan kemampuan finansial dari orang tua siswa yang rata-rata memiliki penghasilan cukup sampai lebih bisa menjadi salah satu alternatif strategi untuk mengatasi permasalahan pengelolaan lingkungan sekolah.

1. Pengelolaan Sekolah sebagai Laboratorium Alam

Laboratorium alam merupakan salah satu alternatif dalam dunia pendidikan untuk semakin meningkatkan motivasi dan hasil belajar siswa. Pola pengajaran dalam kelas lambat laun sudah mulai dikombinasikan dengan kegiatan di luar sekolah dengan tujuan untuk dapat menarik perhatian siswa terhadap KD atau mata pelajaran tertentu.

Pengelolaan sekolah sebagai laboratorium alam diawali dengan tindakan observasi oleh guru bidang studi. Guru memilih lokasi atau lingkungan di lingkungan sekolah yang masih memiliki permasalahana untuk di tangani. Masalah yang dapat dijadikan pilihan adalah kurang tertatanya taman, masih terdapatnya sampah yang belum terolah, rendahnya tingkat keanekaragaman hayati dan masih banyak lagi permasalahan yang lainnya. Permasalahan yang muncul sangat tergantung kepada kondisi sekolah masing masing.Sehingga program ini memungkinkan untuk dilakukan di berbagai sekolah dengan kondisi lingkungan yang bervariatif.

2. Pengelolaan sekolah sebagai laboratorium alam berbasis partisipatif

Partisipatif dalam hal ini dimaksudkan sebagai bentuk kerja sama antara sekolah dengan sumber daya manusia yang ada di lingkungan sekolah untuk menjaga, merawat dan mewujudkan lingkungan sekolah yang asri sebagai wujud adiwiyata.

Dalam misi SMAN 1 Blitar terdapat pernyataan yang menyatakan bahwa adiwiyata merupakan kebutuhan warga sekolah untuk menciptakan lingkungan belajar yang kondusif dan asri untuk meningkatkan mutu pembelajaran.Adiwiyata sebagai sebuah kebutuhan warga sekolah merupakan landasan bertindak demi mewujudkan sekolah yang berbudaya lingkungan.Perwujudan adiwiyata sebagai kebutuhan semua warga sekolah merupakan salah satu misi yang dapat diterapkan dengan prinsip partisipatif.Partisipasi warga sekolah dapat digali melalui kegiatan belajar mengajar dan menjadikan lingkungan sekolah sebagai laboratorium alam.Laboratorium alam merupakan tempat belajar siswa untuk menggali konsep pelajaran dan pada akhirnya siswa berpikir untuk melakukan aksi nyata yang dapat diterapkan di laboratorium alam. Dengan pola sedemikian, kegiatan pengelolaan lingkungan sekolah sebagai laboratorium alam berbasis partisipatif memiliki manfaat secara akademis bagi siswa, pembelajaran yang aktif dan menyenangkan bagi guru serta terpeliharanya lingkungan sekolah demi terwujudnya adiwiyata sebagai kebutuhan warga sekolah.

\section{KESIMPULAN}

Berdasarkan permasalahan dan pembahasan pada bab sebelumnya maka dapat disimpulkan sebagai berikut: 1)Lingkungan sekolah SMA Negeri 1 Blitar dapat dimanfaatkan sebagai laboratorium alam yang memungkinkan para siswa dengan sedikit arahan guru, dapat mengembangkan kemampuan berpikir ilmiah (observasi, menemukan masalah, hipotesis, percobaan, kesimpulan dan tindak lanjut). Bila dikaitkan dengan pembelajaran berbasis Kurikulum 2013, maka penggunaan 
JURNAL PENDIDIKAN: Riset dan Konseptual, Vol. 3 No. 2, April 2019 www.journal.unublitar.ac.id/ip E-ISSN: 2598-2877

P-ISSN: 2598-5175

lingkungan sekolah sebagai laboratorium alam merupakan implementasi pembelajaran dengan pendekatan saintifik. 2)Pemanfaatan lingkungan sekolah sebagai laboratorium alam merupakan wahana warga sekolah untuk berpartisipasi aktif dalam pengelolaan lingkungan yang mencakup pemeliharaan, perawatan dan pelestarian lingkungan sekolah. Melalui kegiatan ini guru menuangkan ide dan gagasan dalam bentuk RPP. RPP yang sudah disusun guru selanjutnya dilaksanakan bersama para siswa. Sementara warga sekolah yang lain berkontribusi dalam hal kebijakan dan pendanaan (kasek, konite), perawatan lingkungan sekolah dilakukan oleh seluruh warga sekolah.

\section{SARAN}

Saran yang dapat dikemukakan dalam artikel ini adalah pemanfaatan lingkungan sekolah sebagai laboratorium alam, dapat dilakukan oleh sekolah lain, bukan hanya SMA Negeri 1 Blitar. Dengan adanya lahan yang cukup luas, SMA Negeri 1 Blitar dapat mengembangkan laboratorium alam dengan kombinasi penataan lingkungan yang sesuai dengan kebutuhan siswa sebagai sarana belajar dan sumber belajar, diharapkan akan mampu meningkatkan motivasi belajar siswa dan hasil belajar siswa.

\section{DAFTAR RUJUKAN}

E. Mulyasa. (2007). Menjadi Guru Profesional. Bandung: Remaja Rosdakarya.

Lilianti, tesis. 2013. Pengelolaan Pembelajaran Biologi Berbasis Contextual Teaching And Learning Di SMAN 2 Sukoharjo. PPS. UM.

Sudrajat, akhmad. 2008. Kompetensi Guru dan Peran Kepala Sekolah.Tersedia: http://akhmadsudrajat.Wordpress.com, diakses tanggal 20 Desember 2012.

Yoga Prathama,srikpsi. 2013. Penerapan Pembelajaran Konstektual Berbasis Masalah Untuk Meningkatkan Prestasi Belajar siswa Dalam Pelajaran Kewargaraan Kelas XI IPA 2 SMAN 2 Bantul. FIP.

Yudiono. 1986. Metode Penelitian. Bandung: Angkasa. 